\title{
Erratum to: Numerical Investigation of Influence of the Martensite Volume Fraction on DP Steels Fracture Behavior on the Basis of Digital Material Representation Model
}

KONRAD PERZYŃSKI, ŁUKASZ MADEJ, JIANGTING WANG, ROMAN KUZIAK, and PETER D. HODGSON

DOI: $10.1007 / \mathrm{s} 11661-015-2797-4$

(C) The Minerals, Metals \& Materials Society and ASM International 2015

Erratum to: METALLURGICAL AND MATERIALS

TRANSACTIONS A, VOLUME 45A,

DECEMBER 2014, pp. 5852-5865

DOI: $10.1007 /$ s11661-014-2579-4

Jiangting Wang's name is correct as presented in this erratum.

KONRAD PERZYŃSKI, Researcher, and ŁUKASZ MADEJ, Professor, are with the AGH University of Science and Technology Al. Mickiewicza 30, 30-059 Cracow, Poland. Contact e-mail: kperzyns@ agh.edu.pl JIANGTING WANG, Researcher, and PETER D. HODGSON, Professor, are with the Functional Fibrous Materials, Institute for Frontier Materials, Deakin University, Geelong, Victoria 3217, Australia. ROMAN KUZIAK, Professor, is with the Institute for Ferrous Metallurgy, ul. K. Miarki 12, 44-100 Gliwice, Poland. The online version of the original article can be found under doi: 10.1007/s11661-014-2579-4.

Article published online 11 February 2015 